\title{
Evaluation of Some Exogenous Colorants Effects on Resin Based Materials Used in Incipient Caries Lesions Therapy
}

\author{
IONUT TARABOANTA, GALINA PANCU*, CRISTINA ANGELA GHIORGHE, CLAUDIU TOPOLICEANU, IRINA NICA, \\ ANDRA CLAUDIA GAMEN ${ }^{1}$, ALEXANDRU IOVAN, SORIN ANDRIAN \\ Grigore T. Popa University of Medicine and Pharmacy of lasi, Faculty of Dental Medicine, 16 Universitatii Str., 700115, Iasi, \\ Romania
}

\begin{abstract}
The aim of this study was to evaluate the potential of coloring of two commercial beverages: coffee and wine, and cigarette smoke, on three materials (ICON infiltration resin, MI Varnish Recaldent, and a sealant based on composite resin) currently used in incipient caries therapy. The study group included 75 extracted teeth that were divided into 3 groups corresponding to each material used. The groups were divided into 5 subgroups that corresponded to each colorant ( $A$. red wine, $B$. coffee, $C$. cigarette smoke, $D$. association of the three colorants, $E$. control group). The coloration degree of the samples was measured both after the moment of coloring (M3) and after polishing (M4). The results showed a significant increase of the coloring degree for the samples subjected to the combined action of the three colorants (M3), for all the three materials used $\left(\Delta E_{1}^{*}: I d=23.56, I I d=25.87, I I d=19.87\right)$, and in terms of the coloring degree after the polishing procedure (M4), a decrease of the values was observed $\left(\Delta E_{2}^{*}: I d=17.56\right.$, Ild $=21.67, I I I=$ 16. 78). In conclusion, both exposure to the two beverages used in the study and cigarette smoke $(C)$ leads to the appearance of color changes, but the most significant changes were obtained by combining the three colorants $(D)$. Also, the polishing procedure leaded to an improvement of the color variation for all three materials.
\end{abstract}

Keywords: colorant, infiltration resin, varnish, composite resin, wine, coffee, smoking

In 2010, DMG Company introduced an innovative technology for the treatment of non-cavitated incipient caries lesions - the ICON method [1-7]. The concept of this method consists in the infiltration of the incipient carious lesions with a methylacrylate-based flowable resin, resulting in a deep sealing, stabilization and stopping the evolution of the carious process [4-8]. It is considered to be a microinvasive method, in which the non-cavitated carious lesions in an initial stage are effectively treated with a photo-activated infiltration resin, without using exploratory drilling, anesthesia, repeated visits, or additional bleaching. The resin has the filling capacity and has a high refractive index that produces the so-called chameleon effect, without the need for color matching [4-9]. One important thing to note is that after the infiltration technique, some of the treated lesions have the ability to lose their opaque effectand harmonize well with the adjacentnatural tooth surface [4-8].

The effect of beverages (especially red wine, tea or coffee) and tobacco on esthetic restorations of different materials (composite resins, compomers, traditional glassionomer cement or resin modified glassionomer cement) was discussed and analyzed and it was found that during a relatively short period major differences may occur [10-12]. The most harmful colorants are: cigarette smoke, coffee, black tea, red wine or their combinations [11-13]. The composition and volume of the organic matrix, the type and volume of filler particles, and the finishing step are important factors that can cause color changes of the composite resin restorations. The extrinsic pigmentations can be caused by a rough surface of the material or by the presence of bacterial plaque on restoration surface (color absorption) [14]. In the literature there is no clear established relationship between the smoking habit and the coloring of the restoration materials, but some previous studies reported the coloring effect of cigarette smoke $[15,16]$.
The effectiveness on maintaining the aesthetic aspect over time has been evaluated in a series of in vitro and in vivo studies [10-12, 15-18]. However, some of these studies (in vitro) fail to simulate perfectly the conditions and the complex action of some factors in the oral environment, therefore, the results of the in vivo studies are contradictory and are probably influenced by an inadequate compliance with the criteria for inclusion and/or exclusion of the study. Additional studies are also required to clarify the aspects regarding the evolution of aesthetic parameters over time and the degree of color influence of different exogenous colorants.

The aim of the study was to evaluate the effect of exogenous colorants (coffee, red wine, cigarette smoke) on resin based materials used in non-cavitated caries lesions treatment (ICON infiltration resin, MI Varnish Recaldent, and a resin based sealant) before and after polishing procedures. The research hypothesis was that the exposure to colorant agents change temporarily the chromatic parameters of the materials used in incipient carious lesions treatment and these parameters return partially or totally to the initial values after a polishing step.

\section{Experimental part}

Our study assessed the coloring potential of two commercial beverages: coffee, red wine and of cigarette smoke on three materials currently used in the therapy of incipient caries. The type of restoration material and their composition are shown in Table 1.

The study followed all the regulations imposed by Ethics and Research Committee of Dental Medicine Faculty, Grigore T. Popa University of Medicine and Pharmacy of lasi and in accordance to some published models [19]. The working protocol followed the scheme proposed by A. Borges in 2014 [20] and is described below in Table 2. 


\begin{tabular}{|l|l|l|l|}
\hline Material type & Material composition & Trade name & Manufacturier \\
\hline $\begin{array}{l}\text { Infiltration } \\
\text { Composite Resin }\end{array}$ & $\begin{array}{l}\text { TEGDMA based resin matrix, } \\
\text { initiators - additives }\end{array}$ & ICON & $\begin{array}{l}\text { DMG, } \\
\text { Germany }\end{array}$ \\
\hline Varnish & $\begin{array}{l}\text { RECALDENT (CPP-ACP) } \\
\text { CPP = Casein phosphopeptides; } \\
\text { ACP = Amorphous Calcium Phosphate }\end{array}$ & $\begin{array}{l}\text { Recaldent MI } \\
\text { Varnish }\end{array}$ & EC Erope \\
\hline Sealant & $\begin{array}{l}\text { 70\%w/w inorganic fillers in a methacrylate } \\
\text { matrix (Bis-GMA, TEGDMA) }\end{array}$ & Grandio Seal & $\begin{array}{l}\text { VOCO GmbH, } \\
\text { Cuxhaven, Germany }\end{array}$ \\
\hline
\end{tabular}

Table 1

MATERIALS INCLUDED IN STUDY

Table 2

EXPERIMENTAL PROTOCOL

\begin{tabular}{c}
$\begin{array}{c}\text { Coloration (coffee, red wine, cigarette smoke, coffee+red wine+cigarette smoke) } \\
\text { Color Measurement (M3) }\end{array}$ \\
\hline Polish \\
\hline Color Measurment (M4)
\end{tabular}

75 premolars ( 150 samples) extracted for orthodontic purposes were included in this study. The premolars were divided into three groups, corresponding to each material used (ICON resin, Recaldent Varnish, Grandio Seal), thus resulting 50 samples for each group. The samples were divided into five subgroups. Immediately after extraction, the teeth were thoroughly washed to remove traces of soft tissue, blood and bacterial biofilm and examined for possible cracks or other defects (incipient cavities, hypoplasia). Teeth with visible defects were excluded. Until the experiment started, the teeth were stored in saline water at room temperature. The teeth were cut using cylindrical diamond burs (Extec Corp, Enfield, CT, USA) at high speed under cooling water. Initially, a horizontal section was made and the root was removed. The crown was cut in mesio-distal direction, obtaining two halves: one facial and one lingual. The surface of the enamel was polished with medium, fine and extra-fine abrasive discs $(320,600$, and 1200 grain) and polished with a $1 \mathrm{~mm}$ diamond bur and a cloth polishing disc (Buehler) thus obtaining rectangular samples of $4 \times 3 \mathrm{~mm}$. They were then subjected to demineralization cycles in order to induce the formation of white-spot lesions [21]. The demineralization solution was composed of $50 \mathrm{mM}$ acetate buffer solution containing $1.28 \mathrm{mM} \mathrm{Ca}\left(\mathrm{NO}_{3}\right) \cdot 4 \mathrm{H}_{2} \mathrm{O}, 0.74 \mathrm{mM}$ $\mathrm{NaH}_{2} \mathrm{PO} \cdot 2 \mathrm{H}_{2} \mathrm{O}$ and $0.03 \mathrm{ppm} \mathrm{F}$ at $\mathrm{pH}^{3}=5.0$. The samples were immersed in the demineralizing solution at $37^{\circ} \mathrm{C}$ for $16 \mathrm{~h}$. The total volume of solution was calculated using 2 $\mathrm{mL} / \mathrm{mm}^{2}$ of the enamel surface. This method produces sub-surface lesions with an average depth of 43um [22].

The samples thus obtained were stored in saline water for $24 \mathrm{~h}$ and subsequently divided into three groups: group I (subjected to ICON infiltration resin therapy), group II (subjected to remineralization therapy with Recaldent MI Varnish), group III (subjected to sealing with Grandio Seal nanohybrid composite resin). The application of the products was performed according to the protocol indicated by the manufacturer. Each group contained 50 samples, divided into 5 subgroups $(5 \times n=10)$. In the study subgroups la, Ila and IIla the samples were subjected to red wine (A) action, in Ib, Il b and IIIb were subjected to coffee (B) solution action, in Ic, IIc and IIIc were subjected to cigarette smoke (C) action, in Id, IId and IIId were subjected to the mixed effect of the three colorants: coffee, red wine and cigarette (D), and in le, lle and Ille the samples were kept in artificial saliva (E) as control group and subjected to any coloring action. The coloring protocol complied with the following conditions: immersion in a colorant at $37^{\circ} \mathrm{C}$, under dark conditions for 24 hours, 7,14 and 21 days, respectively.

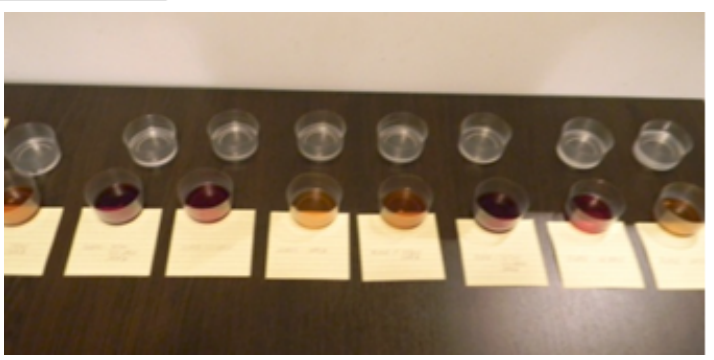

Fig. 1. The samples immersed in coffee solution and red wine

Ertas et al. [23] reported that a $24 \mathrm{~h}$ immersion is the equivalent of a month of coffee consumption. For subgroups Ic, Ilc and IIIc a smoke exposure of 8 min /cycle, 20 times a day was simulated. Subgroups Id, IId and IIId were subjected to the mixed action of the three colorants: coffee, red wine, cigarette. The coloring solutions used in this study were: Nescafe Brasero coffee, producer Nestle Spain; Red Wine (dry red wine, $13.5 \%$ alcohol) Trockener Rotwein Schwaben Wein Merlot/Cabernet Sauvignon producer Cramele Recas SA Romania. During the immersion in beverages, the same quantity of beverage $(30 \mathrm{~mL}$ ) was used for each sample. Between the coloring cycles, the samples were immersed in Fusayama-Mayer artificial saliva ( $30 \mathrm{~mL} / \mathrm{sample}$ ). The composition of saliva used in the study is presented in Table 3.

\begin{tabular}{|l|l|}
\hline \multicolumn{2}{|c|}{ Saliva Fusayama- Mayer } \\
\hline \multicolumn{1}{|c|}{ Composition } & \multicolumn{1}{c|}{$\mathrm{g} / \mathrm{L}$} \\
\hline $\mathrm{NaCl}$ & 0.4 \\
$\mathrm{KCl}$ & 0.4 \\
$\mathrm{CaCl} \cdot 2 \mathrm{H}_{2} \mathrm{O}$ & 0.795 \\
$\mathrm{NaH}_{2} \mathrm{PO}_{4} \cdot 2 \mathrm{H}_{2} \mathrm{O}$ & 0.690 \\
$\mathrm{Na}_{2} \mathrm{~S} \cdot 9 \mathrm{H}_{2} \mathrm{O}$ & 0.005 \\
$\mathrm{Uree}$ & 1.00 \\
\hline
\end{tabular}

Table 3

ARTIFICIAL SALIVA COMPOSITION

Exposure to cigarette smoke was performed in a boxlike device (smoking exposure simulator) made of a transparent acrylic material, hermetically sealed (Fig. 2). This appliance contained two chambers connected through an orifice with a cigarette filter paper. Lit cigarettes were placed in the first chamber provided with external ventilation. The air vapors led the smoke from the first room into the second, where the samples were. To reach the second chamber, the smoke had to pass through the cigarette filter barrier. The second chamber was equipped with another hole in order to release the air vapors.

Polishing procedure was performed after the 21-days exposure period to the coloring agents using the abrasive discs described above. After completion of the coloring cycles and before color determination, all samples were 


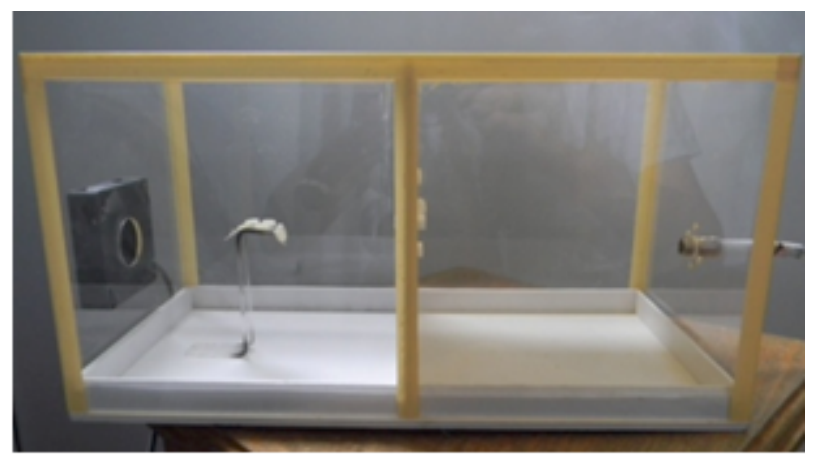

Fig. 2. Samples exposed to cigarette smoke

washed with saline water maintained in artificial saliva for $18 \mathrm{~h}$. Chromatic determinations were performed with Lovibond Reflectance Tintometer RT (Lovibond Brand UK) after 24 hours and 7 days, respectively. The samples were washed with distilled water and dried with air spray before each measurement. The color evaluation ranges were: initially (M1), after demineralization and treatment (M2), after the action of colorants (M3) and after polishing (M4).

Colorimetric differences $\left(\Delta \mathrm{E}^{*}\right)$ were analyzed by the CIE L*a*b* system and were compared for the control subgroup and study subgroups for all three materials [25]. The color parameters L* (brightness), a* (green-red), b* (blueyellow) were measured according to the experimental protocol [25-30]. The differences between $L^{*}\left(\Delta L^{*}\right)$, $a^{*}$ $\left(\Delta a^{*}\right)$, and $b^{*}\left(\Delta b^{*}\right)$ values were determined and the overall color change $\left(\Delta \mathrm{E}^{*}\right)$ was calculated using the following formula (Fig. 4). Also, the evolution of the color changes (initially after coloring and after polishing) was calculated according to the formulas shown below, where $\Delta \mathrm{E}_{1}^{*}$. represents the color change after exposure to the colorants, and $\Delta \mathrm{E}_{2}{ }^{*}$ - represents the color change after the polishing stage, with the help of relationships, which represents computational formulas of color changes evolution [2528]:

$$
\begin{aligned}
& \Delta \mathrm{E}_{\mathrm{ab}} *=\left[(\Delta \mathrm{L} *)^{2}+(\Delta \mathrm{a} *)^{2}+\left(\Delta \mathrm{b}^{*}\right)^{2}\right]^{1 / 2}
\end{aligned}
$$

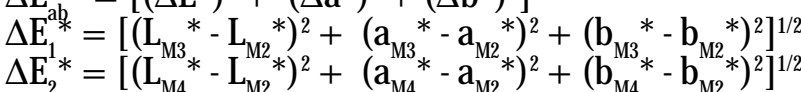

\section{Results and discussions}

SPSS software, version 11.5 was used to analyze the data. The mean value and standard deviation in all subgroups were determined. The data were also analyzed using two-way analysis of variance and Tukey's tests for color measurement after staining and after polishing. A paired t-test was conducted to evaluate if the polishing procedures influenced the specimens color, for each experimental condition. The significance level used was $p$ $<0.05$.

The variations between the mean values and the standard deviation of the $L * a * b *$ parameters for each material (ICON, MI Varnish, Grandio Seal), after the colorant exposure protocol and after polishing procedure are shown in the table below (Table 4).

Analyzing the results, we can observe that color exposure (M3) causes color changes in all three groups of materials. The highest degree of coloring was observed in subgroups $D\left(\Delta E^{*}: I d=23.56, \| d=25.87, \quad I I d=19.87\right.$ ) for all three materials evaluated in the study, the result was probably determined by the association of the action of the three colorants (wine, coffee, cigarette smoke). In descending order, the subgroup $C$ which was subjected to the action of cigarette smoke $\left(\Delta \mathrm{E}^{*}: \mathrm{Ic}=18.23\right.$, IIc $=$ 19.79 , IIIC $=16.21$ ) was followed by the ones colored with wine, the subgroups $\mathrm{A}\left(\Delta \mathrm{E}_{1}^{*}\right.$ : la $=16.23, \mathrm{lla}=17.96$, IIla $=14.23$ ) and finally those subjected to immersion in coffee, subgroups $B\left(\Delta \mathrm{E}_{1}^{*}: \mathrm{Ib}=15.34, \mathrm{Ilb}=16.58, \mathrm{Illb}=\right.$ 12.78). The lowest values were recorded in control subgroups $\mathrm{E}\left(\Delta \mathrm{E}_{1}^{*}:\right.$ le $=5.47$, lle $=6.78$, Ille = 3.65) (Table 4).

Analyzing the color parameter L* (brightness) we can notice that the color exposure (M3) leads to color changes for all materials, therefore, the samples from the control group $E$ reached the peak values $\left(L^{*} \mid \mathrm{l}=78.89\right.$, Ile $=$ 74.23, IIIe = 73.24), followed by subgroup C (cigarette smoke) who reached the second values for samples where ICON resin and Varnish were applied ( $\mathrm{L} * \mathrm{IC}=72.04$, IIC $=$ 71.67) and where Grandio Seal material was used, subgroup B (samples submitted to coffee attack) followed the values recorded by the control group $(L *:|l| b=70.45)$ (Table 4).

Regarding the color parameter a* (green-red), the registered values were also modified, so we notice that in the case of using ICON resin and Varnish, subgroup B recorded the highestvalues $\left(a^{*}: \mathrm{lb}=3.98\right)$, for the samples where Recaldent Varnish was used, the peak value was reached by subgroup $C\left(a^{*}: \| c=3.98\right)$ and in the case of

\begin{tabular}{|c|c|c|c|c|c|c|c|c|c|c|c|c|c|}
\hline & & \multicolumn{4}{|c|}{$\mathrm{I}(\mathrm{ICON})$} & \multicolumn{4}{|c|}{ II (Recaldent MI Varnish) } & \multicolumn{4}{|c|}{ III (Grandio Seal) } \\
\hline & & \multicolumn{2}{|c|}{$\mathrm{MB}$} & \multicolumn{2}{|c|}{ M4 } & \multicolumn{2}{|c|}{ M3 } & \multicolumn{2}{|c|}{ M4 } & \multicolumn{2}{|c|}{$\mathrm{M} 3$} & \multicolumn{2}{|c|}{ M4 } \\
\hline & & mean & SD & mean & SD & mean & SD & mean & SD & mean & SD & mean & SD \\
\hline $\begin{array}{l}\text { Subgroup } \mathbf{A} \\
\text { (red wine) }\end{array}$ & $\begin{array}{l}\mathrm{L}^{+} \\
\mathrm{a}^{+} \\
\mathrm{b}^{+} \\
\Delta \mathrm{E}^{*}\end{array}$ & $\begin{array}{l}62.07 \\
0.98 \\
11.87 \\
16.23\end{array}$ & $\begin{array}{l}.0978 \\
.0231 \\
.0456\end{array}$ & $\begin{array}{l}71.45 \\
0.89 \\
10.87 \\
12.98\end{array}$ & $\begin{array}{l}.0387 \\
.0563 \\
.0256\end{array}$ & $\begin{array}{l}68.96 \\
-2.98 \\
15.25 \\
17.96\end{array}$ & $\begin{array}{l}.0427 \\
.1091 \\
.0287\end{array}$ & $\begin{array}{l}62.45 \\
2.54 \\
12.87 \\
15.35\end{array}$ & $\begin{array}{l}.0379 \\
.0172 \\
.1791\end{array}$ & $\begin{array}{l}66.23 \\
4.35 \\
18.89 \\
14.23\end{array}$ & $\begin{array}{l}.0529 \\
.0781 \\
.1963\end{array}$ & $\begin{array}{l}61.89 \\
3.56 \\
20.12 \\
11.09\end{array}$ & $\begin{array}{l}.0781 \\
.0681 \\
.0662\end{array}$ \\
\hline $\begin{array}{l}\text { Subgroup B } \\
\text { (coffee) }\end{array}$ & $\begin{array}{l}\mathrm{L}^{+} \\
\mathrm{a}^{+} \\
\mathrm{b}^{+} \\
\Delta \mathrm{E}^{+}\end{array}$ & $\begin{array}{l}61.65 \\
3.98 \\
13.65 \\
15.34 \\
\end{array}$ & $\begin{array}{l}.0367 \\
.0671 \\
.0561\end{array}$ & $\begin{array}{l}70.98 \\
2.89 \\
12.42 \\
11.89 \\
\end{array}$ & $\begin{array}{l}.0732 \\
.0541 \\
.0561\end{array}$ & $\begin{array}{l}69.23 \\
2.68 \\
14.32 \\
16.58 \\
\end{array}$ & $\begin{array}{l}.0439 \\
.1087 \\
.0195\end{array}$ & $\begin{array}{l}67.87 \\
1.91 \\
13.37 \\
14.78 \\
\end{array}$ & $\begin{array}{l}.0659 \\
.0361 \\
.0571\end{array}$ & $\begin{array}{l}70.45 \\
3.65 \\
20.34 \\
12.78 \\
\end{array}$ & $\begin{array}{l}.0518 \\
.0781 \\
.1561\end{array}$ & $\begin{array}{l}67.34 \\
2.09 \\
14.34 \\
10.65 \\
\end{array}$ & $\begin{array}{l}.1891 \\
.1681 \\
.0961\end{array}$ \\
\hline $\begin{array}{l}\text { Subgroup C } \\
\text { (cigarette } \\
\text { smoke) }\end{array}$ & $\begin{array}{l}\mathrm{L}^{+} \\
\mathrm{a}^{+} \\
\mathrm{b}^{+} \\
\Delta \mathrm{E}^{+}\end{array}$ & $\begin{array}{l}72.04 \\
3.87 \\
16.87 \\
18.23\end{array}$ & $\begin{array}{l}.0534 \\
.0351 \\
.0452\end{array}$ & $\begin{array}{l}61.04 \\
2.89 \\
14.23 \\
16.78\end{array}$ & $\begin{array}{l}.0679 \\
.0682 \\
.0693\end{array}$ & $\begin{array}{l}71.67 \\
3.98 \\
17.01 \\
19.79\end{array}$ & $\begin{array}{l}.0532 \\
.1962 \\
.0643\end{array}$ & $\begin{array}{l}69.43 \\
2.56 \\
13.47 \\
17.91\end{array}$ & $\begin{array}{l}.0482 \\
.1721 \\
.0671\end{array}$ & $\begin{array}{l}63.56 \\
2.98 \\
13.98 \\
16.21\end{array}$ & $\begin{array}{l}.1681 \\
.0941 \\
.0281\end{array}$ & $\begin{array}{l}69.54 \\
2.09 \\
12.32 \\
13.45\end{array}$ & $\begin{array}{l}.0951 \\
.0497 \\
.1701\end{array}$ \\
\hline $\begin{array}{l}\text { Subgroup D } \\
\text { (red wine + } \\
\text { coffee + } \\
\text { cigarette } \\
\text { smoke) }\end{array}$ & $\begin{array}{l}\mathrm{L}^{+} \\
\mathrm{a}^{+} \\
\mathrm{b}^{+} \\
\Delta \mathrm{E}^{+}\end{array}$ & $\begin{array}{l}57.56 \\
-3.21 \\
19.34 \\
23.56\end{array}$ & $\begin{array}{l}.0562 \\
.0432 \\
.0389\end{array}$ & $\begin{array}{l}63.21 \\
-1.45 \\
16.24 \\
17.56\end{array}$ & $\begin{array}{l}.0794 \\
.0672 \\
.0591\end{array}$ & $\begin{array}{l}67.34 \\
-2.87 \\
17.23 \\
25.87\end{array}$ & $\begin{array}{l}.1093 \\
.0346 \\
.0397\end{array}$ & $\begin{array}{l}58.78 \\
-2.34 \\
18.21 \\
21.67\end{array}$ & $\begin{array}{l}.0578 \\
.1639 \\
.0731\end{array}$ & $\begin{array}{l}65.2 \\
-1.98 \\
15.76 \\
19.87\end{array}$ & $\begin{array}{l}.0861 \\
.0921 \\
.1167\end{array}$ & $\begin{array}{l}62.34 \\
-1.23 \\
14.23 \\
16.78\end{array}$ & $\begin{array}{l}.0959 \\
.1978 \\
.1411\end{array}$ \\
\hline $\begin{array}{l}\text { Subgroup E } \\
\text { (control group) }\end{array}$ & $\begin{array}{l}\mathrm{L}^{+} \\
\mathrm{a}^{+} \\
\mathrm{b}^{+} \\
\Delta \mathrm{E}^{+}\end{array}$ & $\begin{array}{l}78.89 \\
0.98 \\
17.18 \\
5.47 \\
\end{array}$ & $\begin{array}{l}.0213 \\
.0326 \\
.0389\end{array}$ & $\begin{array}{l}72.23 \\
0.78 \\
15.43 \\
3.45 \\
\end{array}$ & $\begin{array}{l}.0741 \\
.0841 \\
.0593\end{array}$ & $\begin{array}{l}74.23 \\
2.15 \\
17.72 \\
6.78 \\
\end{array}$ & $\begin{array}{l}.0619 \\
.0845 \\
.0721\end{array}$ & $\begin{array}{l}76.43 \\
1.21 \\
16.12 \\
4.65 \\
\end{array}$ & $\begin{array}{l}.0498 \\
.1052 \\
.0812\end{array}$ & $\begin{array}{l}73.24 \\
0.98 \\
16.09 \\
3.65\end{array}$ & $\begin{array}{l}.1271 \\
.1181 \\
.0681\end{array}$ & $\begin{array}{l}74.67 \\
0.87 \\
15.98 \\
2.89 \\
\end{array}$ & $\begin{array}{l}.8016 \\
.0599 \\
.1864\end{array}$ \\
\hline & & & & 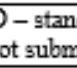 & 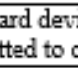 & 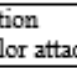 & & & & & & & \\
\hline
\end{tabular}

Table 4

MEAN VALUESAND STANDARD DEVIATIONS OF L*, a* AND b* PARAMETERS AFTER EXPOSURE TO COLORANTS (M3) AND AFTER POLISHING 
using Grandio Seal material, the biggest value of a* parameter was recorded by subgroup A ( $a^{*}$ : Illa $\left.=4.35\right)$ (Table 4).

In what concerns the color parameter b* (blue-yellow) the values have undergone changes as follows: for the samples where ICON resin was used, the highest values was recorded by subgroup $D$ (the association of the three factors with coloristic potential - red wine, coffee and cigarette smoke; $b^{*}:$ Id = 19.34), when Recaldent Varnish was used, the biggest value was recorded by subgroup $E$ (control group; $b^{*}$ Ile = 17.72), followed by the samples from subgroup $D$ ( $b^{*} \| l d=17.23$ ) and when Grandio Seal was used, the maximum value was found in subgroup submitted to coffee attack ( $b *$ : Illb $=20.34$ ) (Table 4).

Regarding color changing after colorants action on different type of materials, it is found that the smallest color changes are observed in the samples when GrandioSeal was applied, followed by those with ICON and those with Recaldent MI Varnish (Table 4).

The analysis of $L^{*} a * b *$ values showed a decrease in brightness values $\left(L^{*}\right)$ for coffee and wine, while parameter a* remains relatively stable for all study subgroups. Samples immersed in the coffee solution showed an increase in parameter b*. Also, for all three materials, an improvement of color parameters is observed after the polishing procedure (M4) (Table 4).

The mean values and the standard deviation of the evolution of color changes after exposure to colorants and after polish are shown in Table 5. Thus, it can be observed that the highest values were reached by the samples from subgroup D (association of red wine, coffee and cigarette smoke) both after exposure to colorants and after polishing $\left(\Delta \mathrm{E}_{1}\right.$ : Id = 46.7; IId = 24.8; III = 28.7; $\Delta \mathrm{E}_{2}$ : Id = 36.3; IId $=18.9 ;$ III = 19.8).

Color assessment can be extremely complex and it can have a direct impact on the dental practice. Maintaining the color of the treated surfaces in time and understanding the patient's demands are fundamental to create aesthetic harmony $[20,24,25]$.

Regarding the type of the material chosen in caries treatment, color changes due to extrinsic colorants depend on the quality of the polymerization, the type and amount of inorganic fillers, and the photo-initiator system [14].

Nowadays, in current practice, researchers propose several methods and techniques in order to analyze the ability of ICON infiltration resin to solve the aesthetic problems of different types of caries lesions [1, 4-9]. However, the results of various studies on color changes induced by exogenous colorants on dental surfaces with incipient caries and on the materials used in their treatment are often controversial [31-35].
Researchers have proposed several methods to evaluate the color changes parameters: colorimetry, guides, color keys, devices, clinical comparison or spectrophotometry $[20,36-40]$. The spectrophotometer allows the evaluation of the $L^{*}, a^{*}$ and $b^{*}$ parameters, meaning the color of the specimens in all axes. $\Delta \mathrm{E}^{*}$ parameter was used as the response variable and it indicated the color change of the samples which has been evaluated over time at two different specific moments, allowing the overall color changes evaluation $[9,14,41]$.

Our study, according to other researches [14, 42, 43], confirms that the over-time action of a range of exogenous colorants (potentially coloring beverages) and exposure to cigarette smoke may cause some color changes on direct restoration materials.

In this study we chose red wine, coffee and cigarette smoke as individual coloring agents and the combination of these three factors due to their frequent use $[3,11,44$ 48]. A number of studies showed that color changes induced by a frequent coffee consumption affects both the structure of the tooth and the restoration materials used for their treatment $[44,45]$. A correlation has been demonstrated between the brown color of the coffee and the polymer chain of the composite resin, a particular composition facilitating the adsorption and penetration of the colorant into the resin $[20,45]$.

In a study conducted by J.K. Park in 2010 [45], it was demonstrated that the samples immersed in coffee showed a change in color to yellow associated with a reduction of brightness, results that are similar to what we also found in current study when analyzing the samples exposed to the coffee solution.

On the other hand, specimens immersed in wine showed a decrease in the $b *$ parameters. The complex combination of pigments that is present in red wine causes changes in $a^{*}$ and $b *$ parameters in the subgroups exposed to wine coloring, similar results being reported by other researchers $[14,20,45]$.

In addition, the presence of alcohol and a low pH could favor the softening of the polymeric material, which could make the adsorption of pigments on the surface of the resin easier, such as the tannins present in the red wine [ 2 , $11,31,44,46]$. Also, the different susceptibility of composite resins to extrinsic colorants can also be influenced by the type of resin matrix due to its different water absorption rate and variable solubility depending on its composition. It has been demonstrated that the absorption of water and other intraoral fluids by the organic component of the resin can lead to color changes and to the degradation of the polymeric matrix [47]. Thus, a high penetration coefficient and low viscosity of the monomer are desirable characteristics to allow the resin to infiltrate into the sub-surface of the carious lesion [5]. The

Table 5

MEAN VALUES AND STANDARD DEVIATION OF COLOR CHANGES AFTER COLORING $\left(\Delta \mathrm{E}_{1}^{*}\right)$ AND AFTER POLISHING $\left(\Delta \mathrm{E}_{2}{ }^{*}\right)$

\begin{tabular}{|c|c|c|c|c|c|c|}
\hline \multirow[t]{2}{*}{ Colorant } & \multicolumn{2}{|l|}{ ICON } & \multicolumn{2}{|c|}{ Recaldent MII Varnish } & \multicolumn{2}{|c|}{ Grandio Seal } \\
\hline & $\Delta \mathrm{E}_{1}^{8}$ & $\Delta \mathrm{E}_{2}{ }^{*}$ & $\Delta \mathrm{E}_{1}^{*}$ & $\Delta \mathrm{E}_{1}^{*}$ & $\Delta \mathrm{E}_{1}^{*}$ & $\Delta \mathrm{E}_{1}^{*}$ \\
\hline $\begin{array}{l}\text { Subgroup A } \\
\text { (red wine) }\end{array}$ & $18.1(2.4)$ & $15.4^{\circ}(3.9)$ & $13.7^{\circ}(1.9)$ & $7.9^{\circ}(2.8)$ & $14.2^{\circ}(3.8)$ & $11.1(2.1)$ \\
\hline $\begin{array}{l}\text { Subgroup B } \\
\text { (coffee) }\end{array}$ & $22.4^{\circ}(4.1)$ & $15.9(4.1)$ & $6.9^{\circ}(2.1)$ & $5.8^{\circ}(1.5)$ & $14.5^{\circ}(4.1)$ & $8.3^{\circ}(4.2)$ \\
\hline $\begin{array}{l}\text { Subgroup C } \\
\text { (cigarette smoke) }\end{array}$ & $34.5^{\circ}(3.9)$ & $24.2(3.6)$ & $17.7^{\circ}(2.3)$ & $15.6^{*}(2.7)$ & $24.3^{\circ}(3.7)$ & $16.6^{\circ}(2.9)$ \\
\hline $\begin{array}{l}\text { Subgroup DE } \\
\text { (red wine }+ \text { coffee }+ \text { cigarette smoke) }\end{array}$ & $46.7^{\circ}(4.2)$ & $36.3(3.9)$ & $24.8(1.9)$ & $18.9^{\circ}(1.7)$ & $28.7^{\circ}(2.8)$ & $19.8^{\circ}(3.5)$ \\
\hline $\begin{array}{l}\text { Subgroup E } \\
\text { (control group) }\end{array}$ & $2.4(1.6) \mathrm{NS}$ & $2.2(0.8) \mathrm{NS}$ & $2.6(1.9) \mathrm{NS}$ & $1.5(1.7) \mathrm{NS}$ & $2.3(1.7) \mathrm{NS}$ & $2.1(0.9) \mathrm{NS}$ \\
\hline
\end{tabular}


combination of experimental TEGDMA, HEMA and ethanol showed satisfactory properties for an infiltrative resin. However, HEMA has a functional hydroxyl group, which gives it hydrophilicity [47]. Thus, although the composition of the infiltration resin (ICON) is not detailed by the manufacturer, it may favor the absorption of water-based colorants and increase the susceptibility of the material for color change. In addition, inhibition of polymerization caused by oxygen and polymerization shrinkage of the infiltration resin may also result in inhomogeneous areas which may facilitate the penetration or adsorption of the colorants [47]. However, a recent study reported that polishing the infiltrated lesions increased their resistance to color changes [4].

Analyzing the results of this study, we can observe that the most affected parameter was L*, indicating low brightness of the samples subjected to exogenous colorants. We have also found in accordance with the results obtained in other studies, that the polishing of materials allows an improvement in color parameters [20, $39,49]$.

This study is an in vitro research and in order to simulate intraoral conditions, further in vivo investigations are necessary, which may also take into account the temperature variations, the dynamic fluctuations of the intraoral $\mathrm{pH}$, the presence of the bacterial biofilm and other conditions that can lead to more precise results.

\section{Conclusions}

The exposure of resin based materials used in the treatment of incipient non-cavitated caries lesions (ICON infiltration resin, MI Varnish, and Grandio Seal sealant) to tobacco smoke, and various coloring solutions (red wine and coffee) determines color changes over time. When comparing the color potential of the beverages and cigarette smoke on resin based materials, the most important color changes have been obtained by the combination of all three colorants, followed by tobacco smoke, red wine, and coffee. The material which presented the highest color variation was Recaldent MI Varnish, followed by ICON infiltration resin, and Grandio-Seal. Polishing procedure improved in color variation of all three tested materials.

\section{References}

1.ROCHA, G.T.C., BORGES, A.B., TORRES, L.M., GOMES, I.S., DE OLIVEIRA, R.S., J. Dent., 39, no.3, 2011, p. 202.

2.PANCU, G., ANDRIAN, S., MOLDOVANU, A., NICA, I., SANDU, A.V., STOLERIU, S., Mat. Plast., 51, no. 4, 2014, p. 428.

3.PANCU, G., ANDRIAN, S., IOVAN, G., GHIORGHE, A., NICA, I., STOLERIU, S., Politici de Sanatate Orala, Infiltrarea cu rasini ICON - 0 noua tehnologie în tratamentul cariilor incipiente, Ed. Gr. T. Popa , U.M.F, Iasi, 2015.

4.PARIS, S., LAUSCH, J., SELJE, T., DÖRFER, C.E., MEYER-LUECKEL, H., J. Dent., 42, no. 4, 2014, p. 432.

5.PARIS, S., MEYER-LUECKEL, H., MUELLER, J., HUMMEL, M., KIELBASSA, A.M., Caries Res., 40, no. 2, 2006, p. 124.

6.PARIS, S., MEYER-LUECKEL, H., Caries Res., 44, no. 1, 2010, p. 47. 7.PARIS, S., MEYER-LUECKEL, H., Quintessence Int., 40, no. 9, 2009, p. 713.

8.PARIS, S., SCHWENDICKE, F., KELTSCH, J., DORFER, C., MEYERLUECKEL, H., Journal of Dentistry Prepublished Apr 11, 2013, doi:pii: S0300-5712(13) 00094-8.

9.PARIS, S., SCHWENDICKE, F., SEDDIG, S., MÜLLER, W.D., DÖRFER, C., MEYER-LUECKEL, H., J. Dent., 41, no. 6, 2013, p. 543.

10.SOARES-GERALDO, D., SCARAMUCCI, T., STEAGALL-JR, W., BRAGA, S.R.M., SO-BRAL, M.A.P., Braz. Oral. Res., 25, no. 4, 2011, p. 369.
11.TOFAN, N., ANDRIAN, S., NICA, I., STOLERIU, S., TOPOLICEANU, C., CHELARIU, R., BOLAT, M., PANCU, G., Rev. Chim. (Bucharest), 67, no. 6, 2016, p. 1144.

12.ERTAS, E., GULER, A.U., YUCEL, A.C., KOEPRUELUE, H., GUELER, E., Dent. Mater. J., 25, no. 2, 2006, p. 371.

13.UM, C.M., RUYTER, I.E., Quintessence Int., 22, 1991, p. 377.

14.GHIORGHE, C.A., IOVAN, G., TOPOLICEANU, C., SANDU, A.V., ANDRIAN, S., Rev. Chim. (Bucharest), 64, no. 12, 2013, p. 1436.

15.LEE, Y.K., POWERS, J.M., J. Mater. Sci. Mater. Med., 18, no.1, 2007, p. 165.

16.OMATA, Y., UNO, S., NAKAOKI, Y., TANAKA, T., SANO, H., YOSHIDA, S., SIDHU, S.K., Dent. Mater. J., 25, no.1, 2006, p. 125.

17.AGHEORGHIESEI CORODEANU, D.T., POROCH, V., 6th LUMEN International Conference on Rethinking Social Action Core Values, 16-19 April 2015, Iasi, Romania, Rethinking Social Action. Core Values, p. 33.

18.STOLERIU, S., IOVAN, G., GEORGESCU, A., SANDU, A.V., ROSCA, M., ANDRIAN, S., Rev. Chim. (Bucharest), 63, no. 1, 2012, p. 68.

19.STOLERIU, S., IOVAN, G., PANCU, G., GEORGESCU, A., SANDU, A.V., ANDRIAN, S., Rev. Chim. (Bucharest), 63, no. 11, 2012, p. 1120.

20.BORGES, A.B., CANEPPELE, T.M.F., LUZ, M., PUCCI, C.R ., TORRES, C.R.G., J. Oper. Dent., 39, no. 4, 2014, p. 433.

21.QUEIROZ, C.S., PAES HARA, A.T., LEME, A.F., CURY, J.A., Braz. Dent. J., 19, no.1, 2008, p. 21.

22.MAGALHAES, A.C., MORON, B.M., COMAR, L.P., WIEGAND, A., BUCHALLA, W., BUZALAF, M.A., Caries Res., 43, no. 6, 2009, p. 474. 23.ERTAS, E., GULER, A.U., YUCEL, A.C., KOEPRUELUE, H., GUELER, E., Dent. Mater. J., 25, no. 2, 2006, p. 371.

24.KIM, S., KIM, E.Y., JEONG, T.S., KIM, J.W., Int. J. Pediatr. Dent., 21, no. 4, 2011, p. 241.

25.HAMMAD, S.M., EL BANNA, M., EL ZAYAT, I., MOHSEN, M.A., Am. J. Dent., 25, no. 1, 2012, p. 3.

26.SCHANDA, J., Colorimetry. Understanding the CIE System, WileyInterscience Publisher, Hoboken, New Jersey, USA, 2007. ISBN:9780470049044.

27.SAVIUC-PAVAL, A.M., SANDU, A.V., POPA, I.M., SANDU, I.C.A., BERTEA, A.P., SANDU, I., Microscopy Research and Technique, 76, no. 6,2013, p. 564.

28.SAVIUC-PAVAL, A.M., SANDU, I., POPA, I.M., SANDU, I.C.A., VASILACHE, V., SANDU, I.G., Rev. Chim. (Bucharest), 63, no. 2, 2012, p. 170.

29.Da SILVA, V.A., Da SILVA, S.A., PECHO, O.E., BACCHI, A., J. of Esthetic and Restorative Dentistry, 30, no. 5, 2018, p.390.

30.CRISTACHE, C.M., OANCEA, L., DIDILESCU, A.C., BURLIBASA, M., TOTU, E.E., Rev. Chim. (Bucharest), 69, no. 2, 2018, p. 463.

31.ARDU, S., CASTIONI, N.V., BENBACHIR, N., KREJCl, I., Quintessence Int., 38, no. 8, 2007, p. 633.

32.BENSON, P., SHAH, A., MILLETT, D., DYER, F., PARKIN, N., VINE, R., J. Orthod., 32, no. 2, 2005, p.102.

33.J ABLONOWSKI, B.L., BARTOLONI, J.A., HENSLEY, D.M., VANDEWALLE, K.S., Quintessence Int., 43, no. 3, 2012, p. 221.

34.TAHER, N.M., ALKHAMIS, H.A., DOWAIDI, S.M., Saudi. Dent. J ., 24, no. 2, 2012, p. 79.

35.POGGIO, C., LOMBARDINI, M., DAGNA, A., CHIESA, M., BIANCHI, S., J. Dent., 37, no. 12, 2009, p. 949.

36.BROOK, A.H., SMITH, R.N., LATH, D.J., Int. Dent. J., 57, no. 5, 2007, p. 324.

37.CHU, S.J., TRUSHKOWSKY, R.D., PARAVINA, R.D., J ournal of Dentistry., 38, no. 2, 2010, p. 2.

38.HORN, D.J ., BULAN-BRADY, J., HICKS, M.L., J. Endod., 24, no. 12, 1998, p. 786.

39.CECI, M., RATTALINO, D., VIOLA, M., BELTRAMI, R., CHIESA, M., COLOMBO, M., POGGIO, C., J. Clin. Exp. Dent., 9, no. 2, 2017, p. 231. 40.STAUDT, C.B., LUSSI, A., JACQUET, J., KILIARIDIS, S., Eur. J. Oral. Sci., 112, no. 3, 2004, p. 237.

41.COREKCI, B., IRGIN, C., MALKOC, S., OZTURK, B., Am. J. Orthod. Dentofacial. Orthop., 138, no. 6, 2010, p. 741.

42.TOPCU, F.T., SAHINKESEN, G., YAMANEL, K., ERDEMIR, U., OKTAY, E.A., ERSAHAN, S., Eur. J. Dent., 3, no. 1, 2009, p. 50. 
43.TUNC, E.S., BAYRAK, S., GULER, A.U., TULOGLU, N., J. Clin. Pediatr. Dent., 34, no. 2, 2009, p. 147.

44.ANFE, T.E., AGRA, C.M., VIEIRA, G.F., J. Esthet. Restor. Dent., 23, no. 4, 2011, p. 260.

45.PARK, J.K., KIM, T.H., KO, C.C., GARCIA-GODOY, F., KIM, H.I., KWON, Y.H., Am. J. Dent., 23, no. 1, 2010, p. 39.

46.ASMUSSEN, E., HANSEN, E.K., Scand. J. Dent. Res., 94, no. 2, 1986, p. 174.
47.BAGHERI, R., BURROW, M.F., TYAS, M., Journal of Dentistry., 33, no. 5,2005, p. 389.

48.J UNGHANNS, K., BACKHAUS, J., TIETZ, U., LANGE, W., RINK, L., WETTERLING, T., DRIESSEN, M., Eur. Psychiatry., 20, no. 5-6, 2005, p. 451.

49.MUNDIM, F.M., GARCIA, LDA. F., PIRES-DE-SOUZA FEDE, C., J. Appl. Oral. Sci., 18, no. 3, 2010, p. 249.

Manuscript received: 9.07.2019 